\title{
Understanding Energy Poverty, Vulnerability and Justice
}

\begin{abstract}
This chapter outlines past and current definitional issues at the nexus of energy poverty, energy vulnerability, energy justice and energy transitions. It traces the historical development of scientific understandings centring on these topics, while exploring their interactions and interdependencies. The chapter starts from the multiple definitional controversies surrounding fuel poverty and energy poverty, to then discuss the different ways in which notions of energy vulnerability and energy justice have enriched traditional understandings. The latter has been achieved, in part, thanks to a fuller appreciation of the services and production chains via which energy circulates across territories.
\end{abstract}

Keywords Energy poverty $\bullet$ Energy vulnerability $\bullet$ Energy justice $\bullet$ Energy transitions $\bullet$ Energy services

\section{INTRODUCTION}

As I pointed out in Bouzarovski (2014), the nexus between energy and poverty has historically been riddled with conceptual discord. For a long time, politicians and scientists alike failed to recognize that a unique set of issues existed at the intersection of these two domains. A government minister in the UK infamously claimed that "people do not talk of "clothes poverty" or "food poverty" and I do not think that it is useful to talk of 
“fuel poverty" either' (Campbell, 1993, p. 58). The establishment of a clear 'fuel poverty' definition in the British academic and decision-making polity (Boardman, 1991) can therefore be considered a pioneering achievement: not only did it necessitate the creation of new state policy, but it also opened the path for scientific debate over the causes, components, symptoms and consequences of domestic energy deprivation that mattered when stipulating what the condition entails.

The official interpretation of fuel poverty in the UK-where this condition is principally seen as the inability to purchase affordable warmth-has proven remarkably resilient despite being challenged in various fora. In the British context, fuel poverty has traditionally been described as a situation in which a household needs to spend more than 10 per cent of its total income (before housing costs) on all fuel used to heat its homes to an acceptable level. Two aspects of this definition are especially significant, not the least in terms of the amount of controversy they have attracted: First, 'needing to spend' refers not to actual expenditure, but to a hypothetical level that is closely related, inter alia, with the thermal energy efficiency of the dwelling. Second, 'acceptable level' is taken to mean that the home is heated in line with the standards recommended by the World Health Organization (WHO) $-18{ }^{\circ} \mathrm{C}$ for bedrooms and $20-21{ }^{\circ} \mathrm{C}$ for living rooms (Boardman, 2010).

The basic principles of this definition were challenged by a governmentsponsored review undertaken by John Hills (2012) at the London School of Economics. This extensive investigation, involving multiple stages of consultation with experts and advocacy organizations, concluded that the existing UK definition has made the fuel poverty measure too sensitive to movements in gas and electricity bills as well as 'the precise assumptions made for what are seen as adequate temperatures for people to live at, and the incomes reported to a survey that is mainly not focussed on income measurement' (Hills, 2012, p. 8). It proposed that the government adopt a new 'Low Income High Cost' (LIHC) indicator about the extent of fuel poverty, which would consider households poor if (i) their 'required fuel costs' are above the median level for the entire population; and (ii) spending that amount would leave them 'with a residual income below the official poverty line' (ibid., p. 9). However, the approach attracted a significant amount of controversy, since it led to a significant reduction in the projected number of fuel-poor households, against a background context where the government 'cut overall support reaching the fuel poor in England by 26 per cent and cut the energy efficiency 
budget reaching fuel poor homes, the most effective long term solution for tackling fuel poverty, by 44 per cent' (Jansz \& Guertler, 2012, p. 2). These debates reflect a broader unease in the academic and policy community, concerning the methods and approaches for measuring the extent of energy poverty (Tirado Herrero, 2017; Maxim et al., 2016; Thomson, Snell, \& Liddell, 2016).

In addition to the notion of 'fuel poverty' - and as noted above-a raft of similar, but not entirely identical, concepts have been used to describe this condition in other settings, including, inter alia, notions of 'energy precariousness', 'energy precarity', 'energy deprivation'. There also exist more narrow terms that refer to some of its symptoms, such as 'cold homes', 'energy non-payment' or 'energy disconnection' (Bouzarovski, 2014; Petrova, 2017; Wilhite, Shove, Lutzenhiser, \& Kempton, 2000). However, one of the most common scientific understandings of 'energy poverty' is one that focuses not on issues of fuel affordability, but rather explores which factors determine the quality and type of energy services received in the home. As we highlighted in Bouzarovski and Petrova (2015), a number of international development organizations and scholars have been focusing on the persistent deficiency of energy infrastructure provision across large parts of Africa, Asia and South America. Despite a long history of international involvement and high-profile political attention, more than 1.2 billion people across the world still lack access to electricity, while a further 2.8 billion have no choice other than traditional biomass for cooking and heating (World Bank, 2014).

Energy poverty in the Global South has received significant academic and policy attention (Gunningham, 2013; Pachauri \& Spreng, 2004; Sagar, 2005), often as a result of its extensive impacts on well-being and health: the inability to access modern fuels in the home means that households are often forced to rely on open fires, which in turn leads to high levels of indoor air pollution. Thus, fumes and smoke from open cooking fires are estimated to contribute to the deaths of 1.3 million people per year, predominantly women and children (González-Eguino, 2015). These circumstances are deemed to exert significant impacts on issues such as personal safety, household time budgets, labour productivity and income (Elias \& Victor, 2005). As such, energy poverty is a highly gendered problem, with women bearing the brunt of the consequences of inadequate energy access, while suffering from systemic discrimination as well as decreased access to resources and decision-making (Abdullahi, 2017; Clancy, Ummar, Shakya, \& Kelkar, 2007; Kumar \& Mehta, 2016; Pachauri \& Rao, 2013). 
Traditionally, energy poverty research in less developed countries has been mainly focused on supply side issues, emphasizing the need for expanding electricity grids based on the experience of developed world countries (Lee, Anas, \& Oh, 1999; Munasinghe, 1990; Rahul Sharma \& Chan, 2016). Work undertaken by organizations such as the World Bank in particular has highlighted the benefits of extending the coverage of power grids into rural areas (Barnes, 2007; Cook, 2011; Foley, 1992; Pereira, Freitas, \& da Silva, 2010), as well as the economic, social and technical barriers to modern energy access (Watson et al., 2011) including the lack of adequate institutional infrastructures and financial capital. This has been demonstrated in case studies from Africa, South America and Southeast Asia alike (Jimenez, 2017; Monyei, Adewumi, Obolo, \& Sajou, 2017; Sovacool \& Ryan, 2016; Urpelainen, 2016). The principal policies to address energy poverty have been largely driven by the 'electrification for development' imperative, as has been the mainstream identification of the driving forces and consequences of the problem.

In more recent years, scientific and policy attention has turned to the poverty-amelioration potential of micro-generation and renewable energy investment as an alternative to top-down power grid expansion (Adkins, Eapen, Kaluwile, Nair, \& Modi, 2010; Bhide \& Monroy, 2011). There has been rising awareness of the cultural and political determinants of household energy transitions towards the use of modern fuels in developing countries (Sehjpal, Ramji, Soni, \& Kumar, 2014). Also of relevance in this context is scholarship on the distributional and fiscal implications of state-led policies to address energy consumption (Dube, 2003; Karekezi \& Kimani, 2002; Lin \& Jiang, 2011), as well as the pathways through which increased access to modern fuels contributes to livelihood improvement and human development more generally (Kaygusuz, 2011; Leite et al., 2016; Ouedraogo, 2013; van Els, de Souza Vianna, \& Brasil Jr., 2012; Zulu \& Richardson, 2013). Debates on the 'other energy crisis' (Eckholm, 1975), therefore, have gradually evolved from a supplydominated logic underscoring the underdevelopment of technical infrastructures to a more nuanced understanding of the multilayered political economies and relations of power that underpin the emergence and persistence of energy poverty (Sovacool, 2012).

To summarize, global issues of energy equity have been historically considered within two relatively separate scientific and policy registers. While discussions and measures surrounding 'fuel poverty' have been largely seen within the context of unaffordable warmth in the home-and 
as such have mainly fallen under the remit of economists, sociologists, environmental scientists and engineers-perspectives on energy poverty in the Global South have been closely articulated in relation to the interdisciplinary field of development studies, in addition to focusing on issues of access, equity and investment in socio-technical systems.

The developed-developing world cleavage can be attributed, in part, to specific historical and geographical trajectories in the scientific recognition of domestic energy deprivation. Here, one can find major distinctions regarding the driving forces of energy and fuel poverty, as well as the policies to address them and their impacts on everyday life (where a clear division emerges about the lack of heating vs. the lack of access to electricity). The health consequences of domestic energy deprivation are perhaps the only area in which similarities exist among dominant understandings, even if the energy poverty literature is predominantly preoccupied on indoor air pollution, while fuel poverty is focused on cold air exposure. At the same time, the fuel-energy poverty binary is not universally applicable: in a limited number of cases, the term 'fuel poverty' has been used to capture the policies and measurement approaches that underpin access to nontraditional energy sources (Hailu, 2012), while some authors use 'fuel poverty' and 'energy poverty' interchangeably to describe conditions in either less developed (Nussbaumer, Bazilian, \& Modi, 2012; Pachauri \& Spreng, 2004) or more developed (Boardman, 2010) countries. Such studies have tended to gloss over-rather than directly engage with-the distinct intellectual and policy traditions that underpin the public recognition and amelioration of the two sets of conditions.

The failure to perceive the complex set of interdependencies between energy and poverty under a common conceptual umbrella has prevented scientists and policymakers from seeing the causes of domestic energy deprivation in an integrated manner. One can thus embrace the emergent terminological messiness developing around energy poverty to argue that the blurring of conventional definitions offers opportunities for advancing scientific and policy debates on the fundamental relationships among energy access, affordability and state policy. This claim is based upon the premise that that all forms of household-scale energy deprivation share the same consequence: a lack of adequate energy services in the home, with its associated discomfort and difficulty. When cross-referenced with the most widely acceptable definition of relative income poverty (a condition with a global definition-see Foster, 1998) fuel and energy poverty alike can be considered under the same conceptual umbrella: as a set of domestic 
energy circumstances that do not allow for participating in the lifestyles, customs and activities that define membership of society (Buzar, 2007a).

\section{Measuring Energy Poverty: A Challenging Task}

In Bouzarovski (2014) I argued that the difficulties associated with defining energy poverty fade in comparison to the complexities involved in measuring its incidence and nature. This has traditionally been an extremely challenging task in light of the specific nature of the problem: it is private (being confined to the domestic domain), temporally and spatially dynamic (by varying over time and in different geographical settings) and culturally sensitive (expectations of energy service are subjective and socially constructed). Nevertheless, three main methods have been used in this context:

- examining the level of energy services in the home (heating, lighting, refrigeration, cooling, etc.) via direct measurement, and comparing the obtained values to a given standard;

- analysing how patterns of household energy expenditure across the population vary in relation to pre-set absolute and relative lines;

- compiling the subjective impressions of households about the level of energy service reached in the home, or collecting self-reported data about housing circumstances that can be used to make indirect judgements about degrees of domestic energy deprivation.

The first approach has not been used on a large scale within the European Union (EU), due to the technical impracticalities and ethical issues associated with it. Adding to this are the difficulties of defining adequate energy service standards, as a result of, in part, cultural specificities: it is known that a home normally considered well-lit and warm in one geographical context may not be seen as such in another (Walker \& Day, 2012). However, national statistical agencies across the EU do gather expenditure data via Household Budget Survey (HBS) platforms; combined with census data and information compiled through other research studies, this has allowed experts to identify the social groups and spatial locations suffering from disproportionately high energy costs. Subjective data relevant to energy poverty is also collected by national statistical agencies, as well as Eurostat's Statistics on Income and Living Conditions (SILC) survey, which was preceded between 1994 and 2001 by the European Community 
Household Panel (ECHP). The two surveys contain a self-reported indicator about the share of population that is 'unable to keep the home adequately warm' that provides the only directly relevant and internationally comparative tool for judging the extent of energy poverty at the EU scale. Both SILC and ECHP also contain a range of objective data about dwelling quality and the material conditions of households, which means that self-reported views of thermal comfort can be cross-referenced against other built environment and economic strain indicators. However, the quality of these data sets has often been put into doubt by experts working in the field (Herrero, 2017; Thomson, Bouzarovski, \& Snell, 2017).

\section{ENERgy SERVICES}

If there is one common thread that connects the multiple energy poverty definitions and measurement methods with respect to the underconsumption of energy in the home, it is the pivotal role of 'energy services' (Fell, 2017). Commonly understood as the 'benefits that energy carriers produce for human well being' (Modi, McDade, Lallement, \& Saghir, 2005, p. 9), energy services allow for shifting the perspective away from 'fuels' such as 'coal, oil, natural gas, and uranium, and even ... sunlight and wind, along with complex technologies such as hydrogen fuel cells, carbon capture and storage, advanced nuclear reactors, and superconducting transmission lines, to name a few' (Sovacool, 201 la, p. 1659) onto the notion that 'people do not demand energy per se but energy services like mobility, washing, heating, cooking, cooling and lighting' (Haas et al., 2008, p. 4013). As a result, policy goals can start to revolve around issues such as achieving 'adequate levels of light rather than delivering kWh of electricity' (Sovacool, 201la, p. 1659). This opens the path for approaching the insecurity of demand-side energy services as a distinct societal challenge, allowing for an 'integrated approach to gauge the resilience of a society to meet the needs of its population ... over longer timescales ahead from various interrelated perspectives' (Jansen \& Seebregts, 2010, p. 1654).

Energy service approaches also highlight the inadequacy of existing measurement frameworks towards understanding and monitoring energy delivery in the home, which is mainly captured by the number of energy units consumed by the carrier, or the effect that the conversion process has on affected spaces (such as levels of temperature or illumination). Neither of these metrics properly describe the utility and satisfaction received by the final user, partly because the effect of the energy service on his or her 
requirements - principally a comfortable and well-functioning home-is largely dependent on subjective variables (Karjalainen, 2007; Petrova, Gentile, Mäkinen, \& Bouzarovski, 2013). It thus becomes important to consider the individual, household and community-level determinants of energy dynamics in the residential environment, by taking into account environmental, cultural, technical and architectural factors in influencing (Aune, 2007; Lutzenhiser, 1992; Stephenson et al., 2010).

Thinking about energy in terms of the domestic functions that it affords also allows for considering the wider technologies and dynamics involved in the operation of modern homes. The relatively simple (and somewhat out of date) classification of energy services provided by authors such as Reister and Devine (1981) and further enshrined in the 'energy ladder' and 'fuel stacking' models (Masera, Saatkamp, \& Kammen, 2000; Nansaior, Patanothai, Rambo, \& Simaraks, 2011; Peng, Hisham, \& Pan, 2010)—space heating, water heating, space cooling, refrigeration, cooking, drying, lighting, electronic services and appliance services-quickly starts to break down when the relevance of other processes in the home is considered within this context. The inherently multifunctional nature of energy services means that carriers with one primary purpose often serve a range of secondary roles, many of which are not explicitly linked to energy. Thus, a wood-burning stove can provide space heating, hot water, cooking, drying and light, as well as a feeling of cosiness, comfort and a focal point in the home (Cupples, Guyatt, \& Pearce, 2007; Petersen, 2008; Reeve, Scott, Hine, \& Bhullar, 2013). At the same time, a single energy service can be supplied by a range of different fuels: 'Illumination, for example, can come from candles, kerosene lamps, or electricity' (Sovacool, 2011 b, p. 218).

Further testifying to the multifaceted nature of energy services is their complex composition, which entails 'different inputs of energy, technology, human and physical capital, and environment (including natural resources)' (Haas et al., 2008, p. 4013). This means that energy services cannot be understood in solely technological or social terms, but rather represent hybrid 'assemblages' (Bennett, 2005; McFarlane, 2011) operating across a multitude of scales and sites, beyond the confines of the home. As such, they consist of 'composite accomplishments generating and sustaining certain conditions and experiences' (Shove, 2003, p. 165) that are deeply embedded in the 'orchestration of devices, systems, expectations and conventions' (Shove, 2003, p. 165). Hence, energy services embody social practices that are "configured by the "hanging together" of institutional 
arrangements, shared cultural meanings and norms, knowledges and skills and varied material technologies and infrastructures' (Walker, 2014, p. 49). The routines that coalesce around systems of provision can thus be studied via a social practice approach that requires 'stepping back from energy itself' (Walker, 2014, p. 49) and moving beyond issues of technological or behavioural efficiency in the series of transformations that lead to the production of useful energy-however important these may be-onto the manner in which end-use energy demand is articulated in time and space (Bridge, Bouzarovski, Bradshaw, \& Eyre, 2013; Jalas \& Rinkinen, 2013; Walker, 2014).

At a more fundamental level, energy services are driven by needs, which reflect what the recipients of this system of provision effectively require: 'A cooked meal, a well lit room, a fast computer with an internet connection, a cold beer, a warm bed, mechanical power for pumping or grinding' (Sovacool, 2011b, p. 218). As such, the fulfilment of energy needs is a crucial component of the functionings that enable individuals to perform their everyday life and achieve well-being (Nussbaum, 2011; Saith, 2001; Sen, 2009). But needs are themselves closely conditioned by the social practices that inform the social expectations and settings in which energy use takes place. This is particularly obvious in the case of electricity, whose technical versatility and flexibility (Smil, 2003) has often prompted actors on the supply side to actively manage and produce energy demand. Despite its intractability and vastness, therefore, the entire electricity system can be seen 'as an element of electricity-consuming social practices, informing what makes sense for householders to do during (and outside) peak periods' (Strengers, 2012, p. 230).

\section{ENERGY VuLnerabiLITy}

Identifying a shared set of energy services required by households in both developed and developing countries can provide an initial step towards the formulation of a planetary approach towards domestic energy deprivation. It is also necessary to highlight any commonalities in the driving forces of energy poverty throughout the supply chain that leads to the delivery of the final service. In developing a common framework for this purpose, Petrova and I (2015) relied on two approaches.

The first is the 'infrastructure and systems of provision' paradigm (Seyfang \& Haxeltine, 2012; Southerton, Chappells, \& Vliet, 2004; Wilhite et al., 2000) which, put briefly, describes the institutional dynamics and material 
cultures surrounding the rise of commodity-specific chains that connect production, distribution and consumption activities. By assigning a 'vertical' logic (Fine, 1993) to the circulation of commodities and services, systems of provision approaches affirm the multiple interdependencies and standardizations that allow for the delivery of specific goods and services to the final consumer. In the case of energy, they bring to light the complex network of activities, infrastructures and resources necessary to provide households with energy. It also becomes apparent that the energy chain (Chapman, 1989) extends well into the home, involving multiple conversions from fuel carriers into end-use services. A household's energy needs are at the final point of this system, while driving its emergence (see Fig. 2.1).

Energy vulnerability thinking provides the second lynchpin of our framework. This approach helps draw a distinction between energy or fuel poverty as a descriptor of a state within a certain temporal frame, on the one hand, and vulnerability as a set of conditions leading to such circumstances, on the other (Bouzarovski, 2013; Hall, Hards, \& Bulkeley, 2013). One of the departure points for the vulnerability approach is the realization

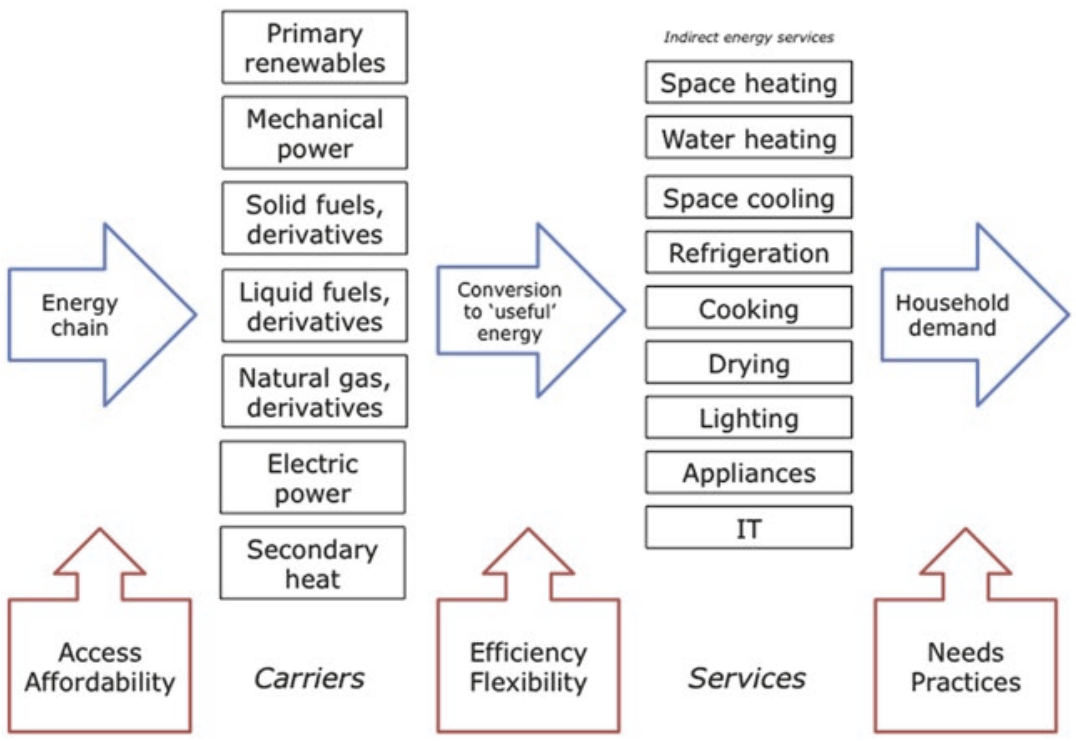

Fig. 2.1 Dimensions influencing the delivery of energy services to the home, and the emergence of domestic energy deprivation. Originally published in Bouzarovski and Petrova (2015) 
that households that are described as 'energy service poor' at a given point in time may exit the condition in the future by changing some of their circumstances and vice versa, fuel or energy poverty may affect households that are not described as such at the moment of consideration (Middlemiss \& Gillard, 2015). In essence, therefore, energy vulnerability thinking is probabilistic: it highlights the factors that affect the likelihood of becoming poor. When combined with the systems of provision approach, energy vulnerability identifies the role of 'horizontal' factors within different components of the energy chain. These extend beyond the affordability-access binary to encompass the nature and structure of the built environment of the home, as well as the articulation of social practices and energy needs.

In the mainstream literature on 'fuel poverty' in the Global North, the dynamics that underpin the condition are mainly identified within the narrow triad of low household incomes, high energy prices and inadequate levels of energy efficiency (Fig. 2.2). But these are only part of the factors that describe the likelihood of experiencing a socially and materially inadequate level of energy services in the home. The interplay between built

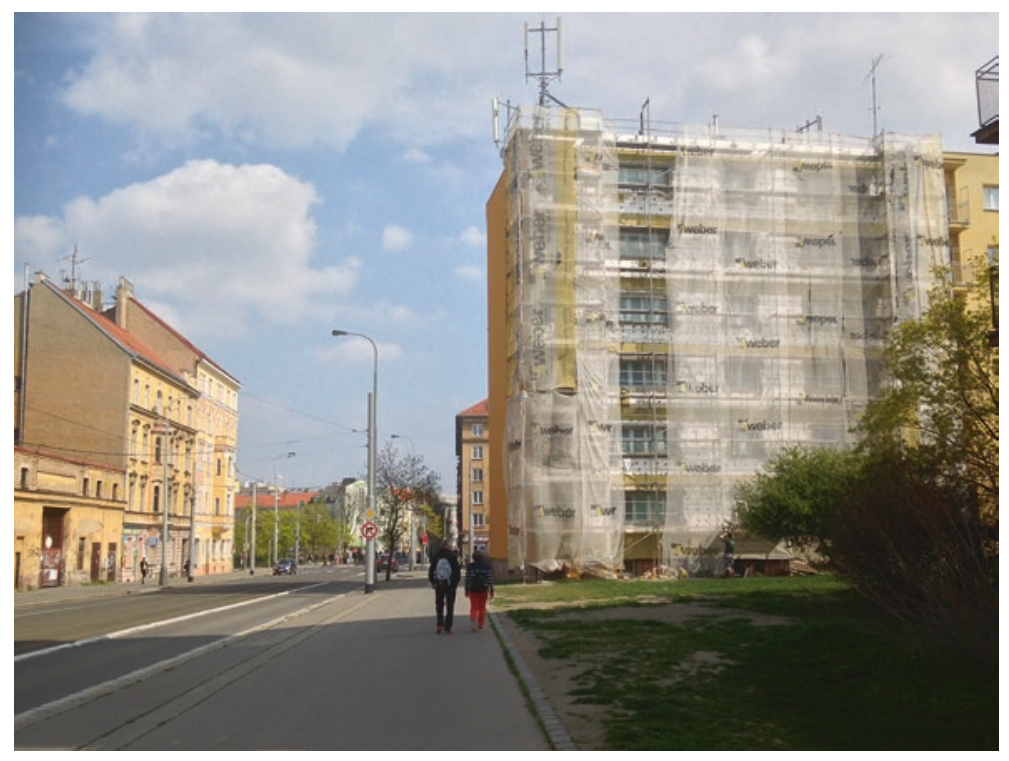

Fig. 2.2 Thermal energy retrofits can have a significant impact on the amelioration of energy poverty - as has been the case in inner-city Prague (photo by Stefan Bouzarovski) 
environment flexibility and energy-related social practices means that domestic energy deprivation may arise as a result of a mismatch between the heating or cooling system installed in the dwelling, on the one hand, and the energy service needed by the occupant household, on the other. For example, electric night storage heating is not the most economic option for households that only use the home in the evenings (Milne \& Boardman, 2000; Osbaldeston, 1984; Rudge, 2012); and district heating systems that do not have individual controls or thermostats may prove unaffordable for residents who end up 'trapped in the heat' at undesirable times of the day (Tirado Herrero \& Urge-Vorsatz, 2012).

In situations where the structural fabric of the building, housing tenure and other legal obstacles do not allow for switching to a more suitable heating system, the household affected by the situation may find itself suffering from inadequate energy services even if it is otherwise able to afford the energy that it consumes, while living in a home that is well insulated (Buzar, 2005, 2007a) (see Fig. 2.3). Moreover, bringing needs into the equation leads, inter alia, to the conclusion that individuals who spend

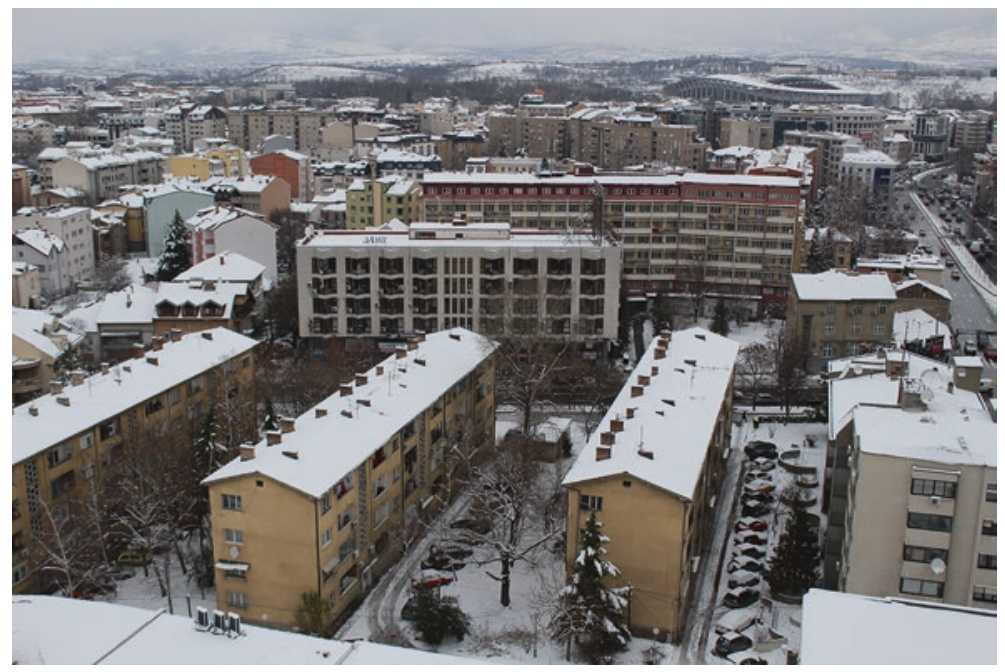

Fig. 2.3 District heating is common in the inner city of Skopje (Macedonia)one of the case study areas of the Energy Vulnerability and Urban Transitions in Europe project (photo by Stefan Bouzarovski) 
a greater degree of the day at home (such as pensioners or unemployed people) or have specific energy requirements (including disability or the presence of small children) are more likely to suffer from domestic energy deprivation than the rest of the population, as their socio-demographic circumstances mean that such households demand above-average amounts of end-use energy (Buzar, 2007b; Roberts, 2008; Wrapson \& DevineWright, 2014; Yohanis, 2012). This situation can transpire irrespective of the affordability of energy prices, or the lack of residential energy efficiency.

Vulnerability thinking can also destabilize dominant understandings of the driving forces of this condition in developing countries. A recognition of the need for energy as a socially necessitated phenomenon above basic biological requirements problematizes the idea that minimum standards can provide for adequate individual functionings. Given the multiple sociotechnical trajectories through which any given service can be procured, this suggests that understandings of energy poverty measurement and indicator frameworks via the lens of particular carriers (in contributions such as, for instance, Pachauri, 2011) could enter into a dialogue with work on the entirety of household needs and situations across the world. Of particular importance here are claims that the households primarily desire an energy supply that is reliable, affordable and accessible (Sovacool, 201 la) whereby 'the use and security of energy services is not ingrained but rather conditioned strongly by income and relative wealth within societies' (Sovacool, 2011a). The linear logic of the energy ladder model-which implies that households move towards more technologically sophisticated energy services as their incomes increase and higher levels of national economic development are reached (Masera et al., 2000; Nansaior et al., 2011; Sovacool, 201 la)—is also destabilized by the multiple functions enabled by energy services, ranging from domestic comfort to personal identity. For example, the use of traditional biomass is predicated upon 'active decision making on the part of individual households according to their preferences and broader lifestyle considerations' (Hiemstra-van der Horst \& Hovorka, 2008, p. 3342) in developing and developed countries alike.

Alongside issues of access to infrastructure (located at the left side of the energy chain) the affordability of energy is a key underpinning of energy vulnerability. This is because the manner in which state bodies and utilities choose to price energy or support particular groups plays a powerful role in determining whether a household is likely to live in conditions of domestic energy deprivation. Injustices of distribution, procedure 
and recognition (Walker \& Day, 2012) become important factors in driving fuel or energy poverty before even considering issues of income, price or efficiency. Indirect subsidies embedded in the energy tariffs, for example, have a significant impact in determining patterns of deprivation (Freund \& Wallich, 1996; Ruggeri Laderchi, Olivier, \& Trimble, 2013). Also of relevance in this case are fiscal or pricing measures targeting particular types of fuel; while taxes on diesel and petrol-and even natural gas-are generally less harmful to the poor, it has been demonstrated that placing the tax burden onto electric bills often highly disproportionately affects poor households (Grave et al., 2016). It has been argued that 'schemes that put a price on carbon emissions further upstream ... have an effect not only on downstream energy prices but also on all other goods and services owing to the higher price of the energy used in their production' (Büchs, Bardsley, \& Duwe, 2011, p. 291). In some cases, fuel or energy poverty assistance schemes can exacerbate the very condition that they are meant to target by privileging particular groups over others. Regulatory obstacles, information scarcity and socio-cultural factors often prevent socially excluded groups from accessing support (Boardman, 2010).

Moving towards a global understanding of energy vulnerability factors also helps highlight the manner in which the driving forces of deprivation can belong to circumstances that are either internal or external to the household. It becomes apparent that external spheres of action tend to be located at the far ends of the provision system - this also includes the domains of needs and practices. Such thinking is not only useful in identifying groups that may be at risk of falling into energy poverty in the future, but can also help place the combination of social, economic, political and infrastructural factors that have contributed to the position of households that are facing the predicament in the present. This is particularly true in the case of developed world urban households living in transitory housing arrangements-mainly young people, tenants in private rental housing and residents of informal settlements-which are difficult to detect and target via conventional policy frameworks (Bouzarovski, Petrova, Kitching, \& Baldwick, 2013; Jencks \& Peterson, 2001; Petrova, 2017; Visagie, 2008). In developing country contexts, the framework highlights the crucial importance of ensuring that the technical and financial availability of energy carriers is matched with socially necessitated household needs. 


\section{ENERgy Transitions}

Processes of structural change in the energy sector-often called 'energy transitions' - have also been known to increase inequality and deprivation; they are hence of key relevance to understandings of energy poverty (Bouzarovski et al., 2017; Bridge et al., 2013). Even though the term 'energy transitions' implies a shift towards a socially desirable end state, there is no consensus among practitioners or academics as to the exact shape of this future as far as the ongoing process of decarbonization is concerned. While such debates have often taken place under the conceptual umbrella of 'sustainability transitions' (Frantzeskaki, Loorbach, \& Meadowcroft, 2012; Lawhon \& Murphy, 2012), the multilayered social and technical nature of energy provision means that low-carbon policies inherently involve a complex interplay of political interests, institutional forces and governance practices. The suggestion that the long-term transformation of energy systems will prove 'to be a messy, conflictual, and highly disjointed process' (Meadowcroft, 2009, p. 323) destabilizes the notion that what is at stake is a linear movement towards a predefined environmentally sustainable condition. Moreover, even if a certain set of technical requirements is achieved, there may be no underlying change to the regulatory practices that surround energy use: the same type of infrastructural outcome can be achieved via different policy means, and without altering the basic principles of system organization (Bridge et al., 2013).

The new 'energy paradigm' (Helm, 2005), therefore, opens fundamental questions about the manner in which different political interests and social formations interact with technological change. Some of these dilemmas have included the role of the state in exercising different governing capacities in steering socio-technical transitions (Baker, Newell, \& Phillips, 2014), the ability of 'community-based initiatives' to generate innovation (Seyfang \& Haxeltine, 2012), the manner in which intermediary organizations assist the implementation of low-carbon strategies (Marvin, 2012) as well as the historical forces involved in shaping deep-seated structural shifts in systems of provision (Smil, 2003).

Historically, energy transitions have been associated with far-reaching shifts in the underpinnings of resource production and distribution, as well as their associated economic and human development patterns. It is claimed that the adoption of low-carbon technology solutions and mitigation strategies brings about multiple benefits in the form of enhanced 
social welfare and reduced inequalities, and that synergies exist between climate change, poverty alleviation and economic development agendas (Tirado Herrero, 2013; Tirado Herrero \& Urge-Vorsatz, 2012). Some of the scholarship in this vein has highlighted the key role of end-use energy services in driving wider socio-technical shifts in society: it has been argued that an improved understanding of energy outputs - rather than the dominant focus on energy outputs - can help explain the relatively slow pace of change in some instances, as well as the emergence of unintended consequences (Grubler, 2012). A distinct body of research has explored the political economies of socio-technical transition (Baker et al., 2014; Meadowcroft, 2009): while acknowledging the pivotal contribution of the 'Multi-Level Perspective' (MLP) in this context, such authors have also highlighted the MLP's shortcomings in terms of the 'assumptions about the nature of state capacity, markets, institutions and infrastructural systems' (Power et al., 2016, p. 12) as well as the manner in which the foregrounding of technology places an emphasis on niche innovations without considering the activities of powerful stakeholders 'whose behaviour cannot be easily shaped by the state' (ibid.). They argue that diverse energy pathways are fundamentally shaped by dynamics of 'power, capacity and autonomy that states have to secure and negotiate' (ibid., p. 11).

Juxtaposing the literatures surveyed above-particularly the suggestions that energy transitions are spatially contingent, imbued with political power and driven by end-use energy demand-suggests that economic and social position of actors and formations implicated in such processes may be deeply affected by structural shifts in energy inputs and outputs alike. This can involve different scales: from nation states whose energy supply may be disrupted to regions that have lost their economic base and consumers who are affected by the decreased availability or increased price of certain fuels (Bouzarovski \& Tirado Herrero, 2015; Krishnan, 2016; Smil, 2003). Recent years have also seen a range of contributions focusing on the social vulnerabilities arising from the nexus of climate change mitigation, adaptation and energy policy (Byrne \& Portanger, 2016). Some of this work has drilled down to the urban scale, to highlight how the governance of metropolitan systems is enmeshed with perceptions and framings of risk (Rocher, 2016). It can thus be argued that transitions render some actors more socially and economically vulnerable to internal shocks and external pressures, creating new inequalities across time and space.

However, the geographic workings of the energy transitions-vulnerability relationship have received little analytical attention, largely because 
energy vulnerability itself remains poorly theorized. Recent energy vulnerability scholarship-whose detailed consideration would extend beyond the confines of this chapter-has emphasized the importance of considering the problem through a spatial and temporal framework, while discussing its social construction and the need to consider why and how a given entity may become or be considered vulnerable (Christmann, Ibert, Kilper, \& Moss, 2012; Philo, 2012; Waite, Valentine, \& Lewis, 2014). Energy vulnerability has been used in a very wide range of contexts, as it can refer to the infrastructural determinants of resource supply and import dependence at a variety of scales, as well as the systemic conditions that allow some entities to become more socially and technically precarious than others (Christie, 2009; Hall et al., 2013; Hiteva, 2013). There is a distinctive literature on household energy vulnerability, understood as a set of circumstances that underpin the risk of falling into fuel and energy poverty. Having applied Spiers' (2000) understanding of 'emic' vulnerability to utility services such as heating and cooling, Middlemiss and Gillard (2015) suggest that energy vulnerability can also be articulated via a bottom-up perspective that characterizes experiences of deprivation.

The material embeddedness of energy vulnerability points to the need for considering the condition though a geographical lens. In the remainder of this book, I consider energy vulnerability as a 'socio-spatial formation' situated at the nexus of political decisions, economic inequalities, organizational practices, on the one hand, and the physical features of place and space, on the other. It should be noted that socio-spatial formations have been theorized extensively in the geography literature, although this body of work has rarely been considered the agency of infrastructural systems. Initial use of the term was motivated by the need for exploring how the political and economic shifts associated with globalization gave rise to specific development patterns and practices of contestation at the urban scale (Amin, 1994). More recent work on the topic has drawn upon regulation theory approaches to emphasize the institutional and political reconfigurations that have underpinned the emergence of entrepreneurial urbanism and the move from 'government to governance' (Mcguirk, 2012). At the same time, assemblage thinking has allowed for socio-spatial formations to be considered as heterogeneous and emergent networks involving the interaction of human and non-human entities via a range of distributed agencies (Anderson \& McFarlane, 2011; Dittmer, 2013). 


\section{Energy Justice}

As Neil Simcock and I (2017) have argued, the application of justice theories and principles to the understanding of energy systems is gaining increasing traction in policy and research circles alike, a movement captured through the emerging concept and frame of 'energy justice' (Jenkins, McCauley, Heffron, Stephan, \& Rehner, 2016). Work that connects energy poverty with various concepts of justice has focused predominantly on inequalities between social groups, to the detriment of spatial forms of disadvantage. As noted above, energy justice studies are typically concerned with three fundamental forms of justice: distributive justice, procedural justice and justice as recognition (McCauley, Heffron, Stephan, \& Jenkins, 2013). Distributive justice relates to fairness in the distribution of resources; procedural justice to fairness in decision-making process and recognition to the degree of respect given to different socio-cultural identities (Schlosberg, 2007).

In recent years, researchers have contended that the issue of energy poverty is a key dimension of the broader energy justice paradigm (Jenkins et al., 2016). Walker and Day's (2012) pioneering contribution claims that, at its core, energy poverty is 'fundamentally a complex problem of distributive injustice' (p. 69); and suggests that this is underpinned by further injustices in recognition and policymaking procedures. Further studies have built upon this work to unpack the philosophical and moral foundations for considering energy poverty to be a form of injustice (Christman \& Russell, 2016; Sovacool, Heffron, McCauley, \& Goldthau, 2016).

Alongside such conceptual claims, more grounded work has sought to unveil actual cases of injustice in the incidence and lived experiences of energy poverty. Snell, Bevan, and Thomson (2015) demonstrate that energy poverty disproportionately impacts disabled people in England, and suggest that this form of distributive injustice is driven by the misrecognition of disabled groups. Other studies have revealed how subsidies for low-carbon technologies that are funded through levies on household electricity bills take up a greater proportion of income from the poor compared to those on high incomes (Boardman, 2010; Oppenheim, 2016; Preston, White, Thumim, \& Bridgeman, 2013; Stockton \& Campbell, 2011), despite low-income groups generally having relatively minor carbon footprints (Jacobson, Milman, \& Kammen, 2005) and often benefiting less from decarbonization-related interventions (Oppenheim, 2016; Walker, 2008). Similar claims have been made about the costs of 
building new nuclear capacity (Garman \& Aldridge, 2015). These contributions lend support to a 'whole-systems' approach to energy justice, highlighting the ways that an injustice experienced at the household level (in this case, energy poverty) can be the result of decisions and mechanisms operating elsewhere in the energy system (Jenkins et al., 2016; McCauley et al., 2013).

A number of contributions have begun to explore links between energy deprivation and energy justice-where the emphasis has mainly been on issues of distribution rather than recognition or procedural justice. Throughout this body of work, injustices have predominantly been examined and evaluated in terms of inequalities between socio-demographic and/or socio-economic groups. The justice implications of specifically geographical forms of inequality have rarely been examined. Although a substantial body of literature demonstrates how the occurrence and prevalence of energy poverty is uneven across space (Burholt \& Windle, 2006; Healy, 2017; Papada \& Kaliampakos, 2016; Thomson \& Snell, 2013), such work has principally focused on the drivers or consequences of energy poverty itself, and does not explicitly engage with questions of justice and injustice.

In order to understand how injustices are produced in different geographical contexts, however, it is important to illuminate the manner in which spatially uneven exposure to energy poverty is driven by deeper socio-material inequalities. There is widespread evidence to suggest that the environmental features of a place are crucial in shaping vulnerability to energy poverty. This spatially variegated assemblage of material elements can be described via the more generic notion of 'landscape', so as to highlight the 'heterogeneity of socio-energetic relations and their dynamics' (Castán Broto, Salazar, \& Adams, 2014, p. 194; also see Bouzarovski, 2014, for a theorization of 'landscapes of vulnerability'). But even if energy poverty is manifested in particular places, the injustices linked to the environmental factors that produce it extend beyond the spatial and temporal horizons of such locales-expressing a contingency that cannot be easily subsumed within the recognition-procedure-distribution triad. This points to yet another way in which a spatial justice approach illuminates landscapes of material deprivation that add to existing understandings of energy justice.

Climatic conditions are perhaps the most obvious example of an 'environmental' characteristic that can determine household-level vulnerabilities to energy poverty. As climate is underpinned by spatial difference and 
change over time, some places are thus more likely to face elevated risks. But the impact of climatic differences always occurs in interaction with the characteristics of the built environment including the energy efficiency of homes, heating systems and appliances (Boardman, 2010), the 'flexibility' of heating systems and infrastructures (Buzar, 2007b) and the availability of suitable and cost-effective energy carriers (Bouzarovski \& Petrova, 2015). These features are all unevenly distributed across space at a variety of scales and themselves reflect variation in the provision of infrastructural services.

There are also multiple variations between and within nation states. Concerning spatial differences within countries, in Greece, Papada and Kaliampakos (2016) have found that areas in colder climatic zones or higher altitudes are characterized by higher numbers of households paying more than 10 per cent of their income on energy bills (also see Katsoulakos, 2011). Healy and Clinch (2004) have studied rates of energy poverty in Ireland, finding that the shares of households affected by the condition vary geographically between 15 and 18.9 per cent, but with more notable differences in terms of absolute figures-rural areas and Dublin record the greatest number of households living in the condition.

Spatial disparities in household incomes and energy prices contribute to the emergence of geographically uneven injustices. Alongside the national scale, these differences also operate within the grain of cities and regions: local concentrations of low-income households are an important feature of elevated degrees of energy poverty in certain places (Morrison \& Shortt, 2008; Walker, Liddell, McKenzie, \& Morris, 2013). Moreover, there is also evidence to suggest that low-income households often live in the worst quality housing, partly because they lack the financial means to invest in energy efficiency measures (Boardman, 2010).

\section{Conclusion}

The variegated understandings of energy services, vulnerability, justice and transitions reviewed above all point to the multiple ways in which household susceptibilities to energy poverty are determined by the material characteristics of residential locations and neighbourhoods. These are highly spatially uneven at a variety of scales (Bouzarovski \& Cauvain, 2016) while being embedded in political systems and decision-making structures. The multiple spatially embedded characteristics of the place in which people live-including less known issues such as inflexible heating systems, energy-inefficient buildings and a lack of access to more suitable 
energy carriers - assemble to create situations of inadequate energy services and high costs (Maxim, Mihai, Apostoaie, \& Maxim, 2017).

Like other forms of inequality (Dorling \& Ballas, 2008; Walker, 2009), therefore, energy poverty is a deeply geographical and political phenomenon. It is unequally distributed and experienced across different places, and is articulated through complex politics of distribution and recognition. One of the main implications of these arguments is that, in terms of vulnerability to energy poverty, where a person lives seems at least as significant as the socio-economic group that they are part of-yet in much of the current literature and policy discourse inequalities and vulnerability tend to be defined in terms of the latter, rather than in socio-technical, housing or locality terms (Moore, 2012). Thus, spatially uneven patterns of energy poverty are the result of processes and injustices operating throughout the whole energy system, along with economic, material and cultural inequalities acting at various scales. This disrupts the production vs. consumption binary (Jenkins et al., 2016) that has traditionally dominated energy studies, while calling attention to the need for understanding how power interests, relations and processes contribute to the rise of energy-related inequalities.

I have also argued that energy transitions are generators of geographically uneven social, political and environmental displacements. These may increase the vulnerability of particular social groups or places; a contingency that is of special relevance to the global movement towards a low carbon future. The geographies of energy poverty, vulnerability and justice, therefore, embody a distinct temporal dimension. The corollary of this claim is that identifying vulnerable areas also needs to take into account predicted changes in energy prices, forms of infrastructure provision and economic inequality. The two chapters that follow return to the European context via a critical examination of the policy context that allows energy poverty to be being addressed and regulated, while reviewing existing knowledge about the extent and nature of the condition across Europe.

\section{REFERENCES}

Abdullahi, A. A. (2017). An analysis of the role of women in curbing energy poverty in Nigeria. Journal of Sustainable Development Studies, 10, 46-50.

Adkins, E., Eapen, S., Kaluwile, F., Nair, G., \& Modi, V. (2010). Off-grid energy services for the poor: Introducing LED lighting in the Millennium Villages Project in Malawi. Energy Policy, 38, 1087-1097. 
Amin, A. (1994). Post-Fordism: A reader. Oxford: Blackwell.

Anderson, B., \& McFarlane, C. (2011). Assemblage and geography. Area, 43, 124-127.

Aune, M. (2007). Energy comes home. Energy Policy, 35, 5457-5465.

Baker, L., Newell, P., \& Phillips, J. (2014). The political economy of energy transitions: The case of South Africa. New Political Economy, 19, 791-818.

Barnes, D. F. (2007). The challenge of rural electrification. In D. F. Barnes (Ed.), The challenge of rural electrification: Strategies for developing countries (pp. 1-17). Washington, DC: RFF Press.

Bennett, J. (2005). The agency of assemblages and the North American blackout. Public Culture, 17, 445 .

Bhide, A., \& Monroy, C. R. (2011). Energy poverty: A special focus on energy poverty in India and renewable energy technologies. Renewable and Sustainable Energy Reviews, 15, 1057-1066.

Boardman, B. (1991). Fuel poverty: From cold homes to affordable warmth. London: Belhaven.

Boardman, B. (2010). Fixing fuel poverty: Challenges and solutions. London: Routledge.

Bouzarovski, S. (2013). Energy poverty in the European Union: Landscapes of vulnerability. Wiley Interdisciplinary Reviews: Energy and Environment. http:// onlinelibrary.wiley.com/doi/10.1002/wene.89/abstract

Bouzarovski, S. (2014). Energy poverty in the European Union: Landscapes of vulnerability. Wiley Interdisciplinary Reviews: Energy and Environment, 3, 276-289.

Bouzarovski, S., \& Cauvain, J. (2016). Spaces of exception: Governing fuel poverty in England's multiple occupancy housing sector. Space and Polity, 20, 310-329.

Bouzarovski, S., Herrero, S. T., Petrova, S., Frankowski, J., Matoušek, R., \& Maltby, T. (2017). Multiple transformations: Theorizing energy vulnerability as a socio-spatial phenomenon. Geografiska Annaler: Series B, Human Geography, 99, 20-41.

Bouzarovski, S., \& Petrova, S. (2015). A global perspective on domestic energy deprivation: Overcoming the energy poverty-fuel poverty binary. Energy Research \& Social Science, 10, 31-40.

Bouzarovski, S., Petrova, S., Kitching, M., \& Baldwick, J. (2013). Precarious domesticities: Energy vulnerability among urban young adults. In Energy justice in a changing climate: Social equity and low-carbon energy (pp. 30-45). London: Zed Books.

Bouzarovski, S., \& Simcock, N. (2017). Spatializing energy justice. Energy Policy, $107,640-648$.

Bouzarovski, S., \& Tirado Herrero, S. (2015). The energy divide: Integrating energy transitions, regional inequalities and poverty trends in the European Union. European Urban and Regional Studies, 24, 69-86. 
Bridge, G., Bouzarovski, S., Bradshaw, M., \& Eyre, N. (2013). Geographies of energy transition: Space, place and the low-carbon economy. Energy Policy, 53, 331-340.

Büchs, M., Bardsley, N., \& Duwe, S. (2011). Who bears the brunt? Distributional effects of climate change mitigation policies. Critical Social Policy, 31, 285-307.

Burholt, V., \& Windle, G. (2006). Keeping warm? Self-reported housing and home energy efficiency factors impacting on older people heating homes in North Wales. Energy Policy, 34, 1198-1208.

Buzar, S. (2005). The institutional trap in the Czech rental sector: Nested circuits of power, space and inequality. Economic Geography, 82, 381-405.

Buzar, S. (2007a). Energy poverty in Eastern Europe: Hidden geographies of deprivation. Aldershot: Ashgate.

Buzar, S. (2007b). When homes become prisons: The relational spaces of postsocialist energy poverty. Environment and Planning A, 39, 1908-1925.

Byrne, J., \& Portanger, C. (2016). Climate change, Energy policy and justice: A systematic review. Analyse \& Kritik, 36, 315-344.

Campbell, R. (1993). Fuel poverty and government response. Social Policy \& Administration, 27, 58-70.

Castán Broto, V., Salazar, D., \& Adams, K. (2014). Communities and urban energy landscapes in Maputo, Mozambique. People, Place and Policy, 8, 192-207.

Chapman, J. D. (1989). Geography and energy: Commercial energy systems and national policy. Harlow: Longman.

Christie, E. H. (2009). Energy vulnerability and EU-Russia energy relations. Journal of Contemporary European Research, 5, 274-292.

Christman, B., \& Russell, H. (2016). Readjusting the political thermostat: Fuel poverty and human rights in the UK. Journal of Human Rights in the Commonwealth, 2. https://doi.org/10.14296/jhrc.v2i2.2273.

Christmann, G. B., Ibert, O., Kilper, H., \& Moss, T. (2012). Vulnerability and resilience from a socio-spatial perspective: Towards a theoretical framework. Erkner: Leibniz-Institut für Regionalentwicklung und Strukturplanung $\mathrm{eV}$ (IRS).

Clancy, J., Ummar, F., Shakya, I., \& Kelkar, G. (2007). Appropriate genderanalysis tools for unpacking the gender-energy-poverty nexus. Gender and Development, 15, 241-257.

Cook, P. (2011). Infrastructure, rural electrification and development. Energy for Sustainable Development, 15, 304-313.

Cupples, J., Guyatt, V., \& Pearce, J. (2007). 'Put on a jacket, you wuss': Cultural identities, home heating, and air pollution in Christchurch, New Zealand. Environment and Planning A, 39, 2883-2898.

Dittmer, J. (2013). Geopolitical assemblages and complexity. Progress in Human Geography, 38, 385-401. 
Dorling, D., \& Ballas, D. (2008). Spatial divisions of poverty and wealth. In T. Ridge \& S. Wright (Eds.), Understanding poverty, wealth and inequality: Policies and prospects (pp. 103-134). Bristol: Policy Press.

Dube, I. (2003). Impact of energy subsidies on energy consumption and supply in Zimbabwe. Do the urban poor really benefit? Energy Policy, 31, 1635-1645.

Eckholm, E. (1975). The other energy crisis: Firewood. Washington, DC: Worldwatch Institute.

Elias, R. J., \& Victor, D. G. (2005). Energy transitions in developing countries: A review of concepts and literature (Program on energy and sustainable development, working paper). Stanford University, Stanford.

Fell, M. J. (2017). Energy services: A conceptual review. Energy Research \& Social Science, 27, 129-140.

Fine, B. (1993). Modernity, urbanism, and modern consumption: A comment. Environment and Planning D: Society and Space, 11, 599-601.

Foley, G. (1992). Rural electrification in the developing world. Energy Policy, 20, $145-152$.

Foster, J. E. (1998). Absolute versus relative poverty. American Economic Review, $88,335-341$.

Frantzeskaki, N., Loorbach, D., \& Meadowcroft, J. (2012). Governing societal transitions to sustainability. International Journal of Sustainable Development, $15,19-36$.

Freund, C. L., \& Wallich, C. I. (1996). The welfare effects of raising household energy prices in Poland. The Energy Journal, 17, 53-77.

Garman, J., \& Aldridge, J. (2015). When the levy breaks: Energy bills, green levies, and a fairer low-carbon transition. London: IPPR.

González-Eguino, M. (2015). Energy poverty: An overview. Renewable and Sustainable Energy Reviews, 47, 377-385.

Grave, K., Breitschopf, B., Ordonez, J., Wachsmuth, J., Boeve, S., Smith, M., ... Schleich, J. (2016). Prices and costs of EU energy. Utrecht: Ecofys Netherlands.

Grubler, A. (2012). Energy transitions research: Insights and cautionary tales. Energy Policy, 50, 8-16.

Gunningham, N. (2013). Managing the energy trilemma: The case of Indonesia. Energy Policy, 54, 184-193.

Haas, R., Nakicenovic, N., Ajanovic, A., Faber, T., Kranzl, L., Müller, A., \& Resch, G. (2008). Towards sustainability of energy systems: A primer on how to apply the concept of energy services to identify necessary trends and policies. Energy Policy, 36, 4012-4021.

Hailu, Y. G. (2012). Measuring and monitoring energy access: Decision-support tools for policymakers in Africa. Energy Policy, 47(Supplement 1), 56-63.

Hall, S. M., Hards, S., \& Bulkeley, H. (2013). New approaches to energy: Equity, justice and vulnerability. Introduction to the special issue. Local Environment, $18,413-421$. 
Healy, J. D. (2017). Housing, fuel poverty and health: A pan-European analysis. Abingdon/New York: Routledge.

Healy, J. D., \& Clinch, J. P. (2004). Quantifying the severity of fuel poverty, its relationship with poor housing and reasons for non-investment in energysaving measures in Ireland. Energy Policy, 32, 207-220.

Helm, D. (2005). The assessment: The new energy paradigm. Oxford Review of Economic Policy, 21, 1-18.

Hiemstra-van der Horst, G., \& Hovorka, A. J. (2008). Reassessing the 'energy ladder': Household energy use in Maun, Botswana. Energy Policy, 36, $3333-3344$.

Hills, J. (2012). Getting the measure of fuel poverty: Final report of the fuel poverty review. London: LSE.

Hiteva, R. P. (2013). Fuel poverty and vulnerability in the EU low-carbon transition: The case of renewable electricity. Local Environment, 18, 487-505.

Jacobson, A., Milman, A. D., \& Kammen, D. M. (2005). Letting the (energy) Gini out of the bottle: Lorenz curves of cumulative electricity consumption and Gini coefficients as metrics of energy distribution and equity. Energy Policy, 33, $1825-1832$.

Jalas, M., \& Rinkinen, J. (2013). Stacking wood and staying warm: Time, temporality and housework around domestic heating systems. Journal of Consumer Culture. https://doi.org/10.1177/1469540513509639.

Jansen, J. C., \& Seebregts, A. J. (2010). Long-term energy services security: What is it and how can it be measured and valued? Energy Policy, 38, 1654-1664.

Jansz, A., \& Guertler, P. (2012). The impact on the fuel poor of the reduction in fuel poverty budgets in England. London: Association for the Conservation of Energy.

Jencks, C., \& Peterson, P. E. (Eds.). (2001). The urban underclass. Washington, DC: Brookings Institution Press.

Jenkins, K., McCauley, D., Heffron, R., Stephan, H., \& Rehner, R. (2016). Energy justice: A conceptual review. Energy Research \& Social Science, 11, 174-182.

Jimenez, R. (2017). Barriers to electrification in Latin America: Income, location, and economic development. Energy Strategy Reviews, 15, 9-18.

Karekezi, S., \& Kimani, J. (2002). Status of power sector reform in Africa: Impact on the poor. Energy Policy, 30, 923-945.

Karjalainen, S. (2007). Gender differences in thermal comfort and use of thermostats in everyday thermal environments. Building and Environment, 42, $1594-1603$.

Katsoulakos, N. (2011). Combating energy poverty in mountainous areas through energy-saving interventions. Mountain Research and Development, 31, 284-292.

Kaygusuz, K. (2011). Energy services and energy poverty for sustainable rural development. Renewable and Sustainable Energy Reviews, 15, 936-947. 
Krishnan, R. (2016). Energy security through a framework of country risks and vulnerabilities. Energy Sources, Part B: Economics, Planning, and Policy, 11, 32-37.

Kumar, P., \& Mehta, S. (2016). Poverty, gender, and empowerment in sustained adoption of cleaner cooking systems: Making the case for refined measurement. Energy Research \& Social Science, 19, 48-52.

Lawhon, M., \& Murphy, J. T. (2012). Socio-technical regimes and sustainability transitions: Insights from political ecology. Progress in Human Geography, 36, 354-378.

Lee, K. S., Anas, A., \& Oh, G.-T. (1999). Costs of infrastructure deficiencies for manufacturing in Nigerian, Indonesian and Thai cities. Urban Studies, 36, 2135-2149.

Leite, J. G. D. B., Leal, M. R. L. V., Nogueira, L. A. H., Cortez, L. A. B., Dale, B. E., da Maia, R. C., \& Adjorlolo, C. (2016). Sugarcane: A way out of energy poverty. Biofuels, Bioproducts and Biorefining, 10, 393-408.

Lin, B., \& Jiang, Z. (2011). Estimates of energy subsidies in China and impact of energy subsidy reform. Energy Economics, 33, 273-283.

Lutzenhiser, L. (1992). A cultural model of household energy consumption. Energy, 17, 47-60.

Marvin, S. (2012). Conceptual framework: Governance, Transitions and Cities. Introduction. In S. Guy, S. Marvin, W. Medd, \& T. Moss (Eds.), Shaping urban infrastructures: Intermediaries and the governance of socio-technical networks (pp. 15-16). London: Routledge.

Masera, O. R., Saatkamp, B. D., \& Kammen, D. M. (2000). From linear fuel switching to multiple cooking strategies: A critique and alternative to the energy ladder model. World Development, 28, 2083-2103.

Maxim, A., Mihai, C., Apostoaie, C.-M., \& Maxim, A. (2017). Energy poverty in Southern and Eastern Europe: Peculiar regional issues. European Journal of Sustainable Development, 6, 247.

Maxim, A., Mihai, C., Apostoaie, C.-M., Popescu, C., Istrate, C., \& Bostan, I. (2016). Implications and measurement of energy poverty across the European Union. Sustainability, 8, 483.

McCauley, D. A., Heffron, R. J., Stephan, H., \& Jenkins, K. (2013). Advancing energy justice: The triumvirate of tenets. International Energy Law Review, 32, 107-110.

McFarlane, C. (2011). The city as assemblage: Dwelling and urban space. Environment and Planning D: Society and Space, 29, 649-671.

Mcguirk, P. (2012). Geographies of urban politics: Pathways, intersections, interventions. Geographical Research, 50, 256-268.

Meadowcroft, J. (2009). What about the politics? Sustainable development, transition management, and long term energy transitions. Policy Sciences, 42, $323-340$. 
Middlemiss, L., \& Gillard, R. (2015). Fuel poverty from the bottom-up: Characterising household energy vulnerability through the lived experience of the fuel poor. Energy Research \& Social Science, 6, 146-154.

Milne, G., \& Boardman, B. (2000). Making cold homes warmer: The effect of energy efficiency improvements in low-income homes. A report to the Energy Action Grants Agency Charitable Trust. Energy Policy, 28, 411-424.

Modi, V., McDade, S., Lallement, D., \& Saghir, J. (2005). Energy services for the Millennium Development Goals. Washington, DC: The International Bank for Reconstruction and Development/The World Bank/ESMAP.

Monyei, C. G., Adewumi, A. O., Obolo, M. O., \& Sajou, B. (2017). Nigeria's energy poverty: Insights and implications for smart policies and framework towards a smart Nigeria electricity network. Renewable and Sustainable Energy Reviews. https://doi.org/10.1016/j.rser.2017.05.237.

Moore, R. (2012). Definitions of fuel poverty: Implications for policy. Energy Policy, 49, 19-26.

Morrison, C., \& Shortt, N. (2008). Fuel poverty in Scotland: Refining spatial resolution in the Scottish Fuel Poverty Indicator using a GIS-based multiple risk index. Health \& Place, 14, 702-717.

Munasinghe, M. (1990). Rural electrification in the third world. Power Engineering Journal, 4, 189.

Nansaior, A., Patanothai, A., Rambo, A. T., \& Simaraks, S. (2011). Climbing the energy ladder or diversifying energy sources? The continuing importance of household use of biomass energy in urbanizing communities in Northeast Thailand. Biomass and Bioenergy, 35, 4180-4188.

Nussbaum, M. C. (2011). Creating capabilities. Cambridge, MA: Harvard University Press.

Nussbaumer, P., Bazilian, M., \& Modi, V. (2012). Measuring energy poverty: Focusing on what matters. Renewable and Sustainable Energy Reviews, 16, 231-243.

Oppenheim, J. (2016). The United States regulatory compact and energy poverty. Energy Research \& Social Science, 18, 96-108.

Osbaldeston, J. (1984). Fuel poverty in UK cities. Cities, 1, 366-373.

Ouedraogo, N. S. (2013). Energy consumption and human development: Evidence from a panel cointegration and error correction model. Energy, 63, $28-41$.

Pachauri, S. (2011). Reaching an international consensus on defining modern energy access. Current Opinion in Environmental Sustainability, 3, 235-240.

Pachauri, S., \& Rao, N. D. (2013). Gender impacts and determinants of energy poverty: Are we asking the right questions? Current Opinion in Environmental Sustainability, 5, 205-215.

Pachauri, S., \& Spreng, D. (2004). Energy use and energy access in relation to poverty. Economic and Political Weekly, 39, 271-278. 
Papada, L., \& Kaliampakos, D. (2016). Measuring energy poverty in Greece. Energy Policy, 94, 157-165.

Peng, W., Hisham, Z., \& Pan, J. (2010). Household level fuel switching in rural Hubei. Energy for Sustainable Development, 14, 238-244.

Pereira, M. G., Freitas, M. A. V., \& da Silva, N. F. (2010). Rural electrification and energy poverty: Empirical evidences from Brazil. Renewable and Sustainable Energy Reviews, 14, 1229-1240.

Petersen, L. K. (2008). Autonomy and proximity in household heating practices: The case of wood-burning stoves. Journal of Environmental Policy \& Planning, $10,423-438$.

Petrova, S. (2017). Encountering energy precarity: Geographies of fuel poverty among young adults in the UK. Transactions of the Institute of British Geographers. http://onlinelibrary.wiley.com/doi/10.1111/tran.12196/abstract.

Petrova, S., Gentile, M., Mäkinen, I. H., \& Bouzarovski, S. (2013). Perceptions of thermal comfort and housing quality: Exploring the microgeographies of energy poverty in Stakhanov, Ukraine. Environment and Planning A, 45, $1240-1257$.

Philo, C. (2012). Security of geography/geography of security. Transactions of the Institute of British Geographers, 37, 1-7.

Power, M., Newell, P., Baker, L., Bulkeley, H., Kirshner, J., \& Smith, A. (2016). The political economy of energy transitions in Mozambique and South Africa: The role of the Rising Powers. Energy Research \& Social Science, 17, 10-19.

Preston, I., White, V., Thumim, J., \& Bridgeman, T. (2013). Distribution of carbon emissions in the UK: Implications for domestic energy policy. York: Joseph Rowntree Foundation.

Rahul Sharma, K., \& Chan, G. (2016). Energy poverty: Electrification and wellbeing. Nature Energy, 1, 16171.

Reeve, I., Scott, J., Hine, D. W., \& Bhullar, N. (2013). 'This is not a burning issue for me': How citizens justify their use of wood heaters in a city with a severe air pollution problem. Energy Policy, 57, 204-211.

Reister, D. B., \& Devine, W. D., Jr. (1981). Total costs of energy services. Energy, $6,305-315$.

Roberts, S. (2008). Demographics, energy and our homes. Energy Policy, 36, $4630-4632$.

Rocher, L. (2016). Governing metropolitan climate-energy transition: A study of Lyon's strategic planning. Urban Studies. https://doi.org/10.1177/004209 8015624851 .

Rudge, J. (2012). Coal fires, fresh air and the hardy British: A historical view of domestic energy efficiency and thermal comfort in Britain. Energy Policy, 49, $6-11$.

Ruggeri Laderchi, C., Olivier, A., \& Trimble, C. (2013). Balancing act: Cutting energy subsidies while protecting affordability. Washington, DC: The World Bank. 
Sagar, A. D. (2005). Alleviating energy poverty for the world's poor. Energy Policy, $33,1367-1372$.

Saith, R. (2001). Capabilities: The concept and its operationalisation. Oxford: Queen Elizabeth House.

Schlosberg, D. (2007). Defining environmental justice: Theories, movements, and nature. Oxford: Oxford University Press.

Sehjpal, R., Ramji, A., Soni, A., \& Kumar, A. (2014). Going beyond incomes: Dimensions of cooking energy transitions in rural India. Energy, 68, 470-477.

Sen, A. (2009). The idea of justice. Cambridge: Belknap Press/Harvard University Press.

Seyfang, G., \& Haxeltine, A. (2012). Growing grassroots innovations: Exploring the role of community-based initiatives in governing sustainable energy transitions. Environment and Planning-Part C, 30, 381-400.

Shove, E. (2003). Comfort, cleanliness and convenience: The social organization of normality. Oxford: Berg.

Smil, V. (2003). Energy at the crossroads: Global perspectives and uncertainties. Cambridge: MIT Press.

Snell, C., Bevan, M., \& Thomson, H. (2015). Justice, fuel poverty and disabled people in England. Energy Research \& Social Science, 10, 123-132.

Southerton, D., Chappells, H., \& van Vliet, B. (Eds.). (2004). Sustainable consumption: The implications of changing infrastructures of provision. Cheltenham: Edward Elgar Publishing.

Sovacool, B. K. (2011a). Conceptualizing urban household energy use: Climbing the 'Energy Services Ladder'. Energy Policy, 39, 1659-1668.

Sovacool, B. K. (201 lb). Security of energy services and uses within urban households. Current Opinion in Environmental Sustainability, 3, 218-224.

Sovacool, B. K. (2012). The political economy of energy poverty: A review of key challenges. Energy for Sustainable Development, 16, 272-282.

Sovacool, B. K., Heffron, R. J., McCauley, D., \& Goldthau, A. (2016). Energy decisions reframed as justice and ethical concerns. Nature Energy, 1, 16024.

Sovacool, B. K., \& Ryan, S. E. (2016). The geography of energy and education: Leaders, laggards, and lessons for achieving primary and secondary school electrification. Renewable and Sustainable Energy Reviews, 58, 107-123.

Spiers, J. (2000). New perspectives on vulnerability using emic and etic approaches. Journal of Advanced Nursing, 31, 715-721.

Stephenson, J., Barton, B., Carrington, G., Gnoth, D., Lawson, R., \& Thorsnes, P. (2010). Energy cultures: A framework for understanding energy behaviours. Energy Policy, 38, 6120-6129.

Stockton, H., \& Campbell, R. (2011). Time to reconsider UK energy and fuel poverty policies? York: Joseph Rowntree Foundation.

Strengers, Y. (2012). Peak electricity demand and social practice theories: Reframing the role of change agents in the energy sector. Energy Policy, 44, 226-234. 
Thomson, H., Bouzarovski, S., \& Snell, C. (2017). Rethinking the measurement of energy poverty in Europe: A critical analysis of indicators and data. Indoor and Built Environment. http://journals.sagepub.com/doi/abs/10.1177/14 20326 X17699260.

Thomson, H., \& Snell, C. (2013). Quantifying the prevalence of fuel poverty across the European Union. Energy Policy, 52, 563-572.

Thomson, H., Snell, C., \& Liddell, C. (2016). Fuel poverty in the European Union: A concept in need of definition? People Place and Policy, 10, 5-24.

Tirado Herrero, S. (2013). Fuel poverty alleviation as a co-benefit of climate investments: Evidence from Hungary (Doctoral thesis). Budapest: Central European University.

Tirado Herrero, S. (2017). Energy poverty indicators: A critical review of methods. Indoor and Built Environment, 26, 1018-1031.

Tirado Herrero, S., \& Urge-Vorsatz, D. (2012). Trapped in the heat: A postcommunist type of fuel poverty. Energy Policy, 49, 60-68.

Urpelainen, J. (2016). Energy poverty and perceptions of solar power in marginalized communities: Survey evidence from Uttar Pradesh, India. Renewable Energy, 85, 534-539.

van Els, R. H., de Souza Vianna, J. N., \& Brasil, A. C. P., Jr. (2012). The Brazilian experience of rural electrification in the Amazon with decentralized generation-The need to change the paradigm from electrification to development. Renewable and Sustainable Energy Reviews, 16, 1450-1461.

Visagie, E. (2008). The supply of clean energy services to the urban and periurban poor in South Africa. Energy for Sustainable Development, 12, 14-21.

Waite, L., Valentine, G., \& Lewis, H. (2014). Multiply vulnerable populations: Mobilising a politics of compassion from the 'capacity to hurt'. Social is Cultural Geography, 15, 313-331.

Walker, G. (2008). Decentralised systems and fuel poverty: Are there any links or risks? Energy Policy, 36, 4514-4517.

Walker, G. (2009). Beyond distribution and proximity: Exploring the multiple spatialities of environmental justice. Antipode, 41, 614-636.

Walker, G. (2014). The dynamics of energy demand: Change, rhythm and synchronicity. Energy Research \& Social Science, 1, 49-55.

Walker, G., \& Day, R. (2012). Fuel poverty as injustice: Integrating distribution, recognition and procedure in the struggle for affordable warmth. Energy Policy, 49, 69-75.

Walker, R., Liddell, C., McKenzie, P., \& Morris, C. (2013). Evaluating fuel poverty policy in Northern Ireland using a geographic approach. Energy Policy, 63, $765-774$.

Watson, J., Byrne, R., Morgan Jones, M., Tsang, F., Opazo, J., Fry, C., ... \& Castle-Clarke, S. (2011). What are the major barriers to increased use of modern energy services among the world's poorest people and are interventions to overcome these effective? CEE Review 11-004. Collaboration for Environmental Evidence: 
www.environmentalevidence.org/ SRl1004.html. Bangor: Collaboration for Environmental Evidence.

Wilhite, H., Shove, E., Lutzenhiser, L., \& Kempton, W. (2000). The legacy of twenty years of energy demand management: We know more about individual behaviour but next to nothing about demand. In Society, behaviour, and climate change mitigation (pp. 109-126). Dordrecht: Springer.

World Bank. (2014). Energy-The facts. http://web.worldbank.org/WBSITE/ EXTERNAL/TOPICS/EXTENERGY2/0, contentMDK:22855502 pag ePK: $210058 \sim$ piPK:210062 theSitePK:4114200,00.html

Wrapson, W., \& Devine-Wright, P. (2014). 'Domesticating' low carbon thermal technologies: Diversity, multiplicity and variability in older person, off grid households. Energy Policy, 67, 807-817.

Yohanis, Y. G. (2012). Domestic energy use and householders' energy behaviour. Energy Policy, 41, 654-665.

Zulu, L. C., \& Richardson, R. B. (2013). Charcoal, livelihoods, and poverty reduction: Evidence from sub-Saharan Africa. Energy for Sustainable Development, 17, 127-137.

Open Access This chapter is distributed under the terms of the Creative Commons Attribution 4.0 International License (http://creativecommons.org/licenses/ by $/ 4.0 /$ ), which permits use, duplication, adaptation, distribution and reproduction in any medium or format, as long as you give appropriate credit to the original author(s) and the source, a link is provided to the Creative Commons license and any changes made are indicated.

The images or other third party material in this chapter are included in the work's Creative Commons license, unless indicated otherwise in the credit line; if such material is not included in the work's Creative Commons license and the respective action is not permitted by statutory regulation, users will need to obtain permission from the license holder to duplicate, adapt or reproduce the material.

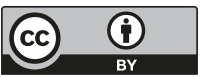

